Pontifícia $U_{\text {niversidade }} C_{\text {atólica }}$

Bernardo Kulnig Pagnoncelli

\title{
Sample average approximation for chance constrained programming
}

\section{TESE DE DOUTORADO}

Thesis presented to the Postgraduate Program in Mathemtics of the Departamento de Matemática, PUC-Rio as partial fulfillment of the requirements for the degree of Doutor em Matemática
Adviser
Prof. Carlos Tomei
Co-Adviser:
Prof. Shabbir Ahmed
Co-Adviser:
Prof. Alexander Shapiro
Co-Adviser: Prof. Humberto José Bortolossi

Rio de Janeiro

February 2009 


\section{Pontifícia $U_{\text {niversidade }}$ Católica $_{\text {a }}$ DO RIO DE JANEIRO \\ Bernardo Kulnig Pagnoncelli Sample average approximation for chance constrained programming}

Thesis presented to the Postgraduate Program in Mathematics, of the Departamento de Matemática do Centro Técnico Científico da PUC-Rio, as partial fulfillment of the requirements for the degree of Doutor.

$$
\begin{array}{r}
\text { Prof. Carlos Tomei } \\
\text { Adviser } \\
\text { Departamento de Matemática - PUC-Rio }
\end{array}
$$

Prof. Shabbir Ahmed

Co-Adviser

H. Milton Stewart School of Industrial \& Systems Engineering - Georgia Institute of Technology

Prof. Alexander Shapiro

Co-Adviser

H. Milton Stewart School of Industrial \& Systems Engineering - Georgia Institute of Technology

Prof. Humberto José Bortolossi Co-Adviser Instituto de Matemática - UFF

Prof. Hélio Côrtes Vieira Lopes Departamento de Matemática - PUC-Rio

Prof. Cristiano Fernandes Departamento de Engenharia Elétrica - PUC-Rio

Prof. Alexandre Street Departamento de Engenharia Elétrica - PUC-Rio

Prof. Hélio dos Santos Migon Instituto de Matemática - UFRJ

Prof. Beatriz Vaz de Melo Mendes Instituto de Matemática — UFRJ

Prof. Roberto Imbuzeiro IMPA

Prof. José Eugenio Leal Coordenador Setorial do Centro Técnico Científico - PUC-Rio 
All rights reserved.

\section{Bernardo Kulnig Pagnoncelli}

Bernardo Kulnig Pagnoncelli obtained his B.Sc. diploma in pure mathematics from PUC-Rio in 2002 and his M.Sc. title in applied mathematics in 2004, with the dissertation "Applications of the tensor product in numerical analysis", under the supervision of Carlos Tomei. He joined the Ph.D. program at PUC-Rio in March 2005 and was invited to spend 2007 at H. Milton Stewart School of Industrial Systems \& Engineering Department at the Georgia Institute of Technology (Atlanta, U.S.A.) by Professor Shabbir Ahmed, one of his co-advisers.

Bibliographic data

Pagnoncelli, Bernardo K.

Sample average approximation for chance constrained programming / Bernardo Kulnig Pagnoncelli; adviser: Carlos Tomei; co-adviser: Shabbir Ahmed et.al. - 2009.

53 f: il. ; $30 \mathrm{~cm}$

Tese (Doutorado em Matemática) - Pontifícia Universidade Católica do Rio de Janeiro, Rio de Janeiro, 2009.

Inclui bibliografia.

1. Matemática - Teses. 2. Stochastic Programming. 3. Chance Constraints. 4. Sampling Methods. 5. Provisioning problem. I. Tomei, Carlos. II. Ahmed, S.. III. Pontifícia Universidade Católica do Rio de Janeiro. Departamento de Matemática. IV. Título.

CDD: 510 


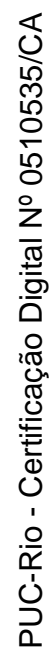

À minha mulher Daniela e aos meus pais Dante e Zuza 


\section{Acknowledgments}

To my Adviser Carlos Tomei for the constant help and friendship during those four years and for always challenging me to do my best. Thank you for placing your bets on a different project and for believing in my potential.

To Shabbir Ahmed for the invitation to spend one year at Georgia Tech under his supervision. Thank you for showing me how to do research in stochastic programming and for all the support during my stay in Atlanta.

To Alexander Shapiro for participating so lively in my research project and for always being available to answer my questions with infinite patience.

To Humberto Bortolossi for inviting me to join a series of weekly seminars during my $\mathrm{PhD}$, which were my very first contact with stochastic programming. Thank you for all the collaboration we had during those four years and I hope we will continue to work together for a long time.

To the members of my committee for the careful reading of the manuscript and for the the suggestions that certainly made the text clearer.

To Helder Inacio for helping me with computational issues on the thesis that made my life a lot easier. Many thanks for listening carefully to me while I spoke about my work and for the suggestions of improvement of the text. Thank you for the friendship during my stay at Georgia Tech and for the uncountable soccer matches.

To Ricardo, Marta and Felipe Fukasawa for everything they did for me and for my wife during our stay in Atlanta. Your help, advice and friendship were very important to us and without them our life at Georgia Tech would have been harder and less funny.

To Felipe Pina and Marcos Lage for the help and suggestions that contributed directly to the improvement of the thesis.

To all the great friends I made in Atlanta: Yao-Hsuan Chen, Claudio Santiago, Daniel Faissol, Eliana \& Jim, Luiz \& Diana, Roberto \& Mariana, Luciano \& Denise, Danny \& Johnny, Daniel \& Lívia and Lili.

To all my friends at PUC for the support and friendship, in particular Miguel Schnoor, Aldo Ferreira da Silva, Renato Zanforlin (in memoriam), Eduardo Teles, Guilherme Frederico Lima, Regina Fukuda, João Romanelli, José Cal Neto, Yuri Ki, Jessica Kubrusly, Juliana Valério, Kennedy Pedroso, Renato Adelino, André Carneiro, Marina Dias, Débora Mondaini, Carlos Peñafiel, Inês de Oliveira, Fábio de Souza, João Domingos, Lhaylla Crissaff, Luiz Felipe França.

To all the Professors of the Mathematics Department at PUC-Rio for the inestimable contribution to my education, specially Fred Palmeira. 
To my friends Diogo Haddad, Diogo Montes, Paula Abreu, Leandro \& Tatiana, Flávia Cordeiro, Beatriz Malajovich, Tania Vasconcelos, Sérgio Almaraz, Lucas Sigaud and Priscila Almeida.

To my grandmother Deliza Pagnoncelli and to my brother Eduardo Pagnoncelli for always thinking I was doing something important.

To Néia for tolerating me all those years and for providing me my every day food.

To my family and my wife's family for the constant support.

To the staff of the Mathematics Department at PUC-Rio Kátia, Creuza, Ana, Orlando and Otávio for always being so nice to me.

To PUC-Rio, FUNENSEG and CAPES for the financial support. 


\section{Abstract}

Pagnoncelli, Bernardo K.; Tomei, Carlos; Ahmed, S.; Shapiro, A.; Bortolossi, Humberto José. Sample average approximation for chance constrained programming. Rio de Janeiro, 2009. 53p. TESE DE DOUTORADO - Department of Mathematics, Pontifícia Universidade Católica do Rio de Janeiro.

We study sample approximations of chance constrained problems through the sample average approximation (SAA) approach and prove the related convergence properties. We discuss how to use the SAA method to obtain good candidate solutions and bounds for the optimal value of the original problem. In order to tune the parameters of SAA, we apply the method to two chance constrained problems. The first is a linear portfolio selection problem with returns following a multivariate lognormal distribution. The second is a joint chance constrained version of a simple blending problem. We conclude with a more demanding application of SAA methodology to the determination of the minimum provision an economic agent must have in order to meet a series of future payment obligations with sufficiently high probability.

\section{Keywords}

Stochastic Programming. Chance Constraints. Sampling Methods. Provisioning problem. 


\section{Resumo}

Pagnoncelli, Bernardo K.; Tomei, Carlos; Ahmed, S.; Shapiro, A.; Bortolossi, Humberto José. Método da aproximação amostral para restrições probabilísticas. Rio de Janeiro, 2009. 53p. Tese de Doutorado — Departamento de Matemática, Pontifícia Universidade Católica do Rio de Janeiro.

Estudamos aproximações amostrais de problemas com restrições probabilísticas através da aproximação pela média amostral (SAA) e demonstramos as propriedades de convergência relacionadas. Utilizamos SAA para obter bons candidatos à solução e cotas estatísticas para o valor ótimo do problema original. Para ajustar corretamente parâmetros, aplicamos o método a dois problemas com restrições probabilísticas. O primeiro é um problema de seleção de portfolio linear com retornos seguindo uma distribuição lognormal multivariada. O segundo é uma versão com restrições probabilísticas conjuntas de um problema da mistura simplificado. Concluímos com uma aplicação mais exigente ao problema de se determinar a provisão mínima que um agente econômico deve ter de forma a satisfazer uma série de obrigações futuras com probabilidade suficientemente alta.

\section{Palavras-chave}

Otimização Estocástica. Restrições Probabilísticas. Métodos Amostrais. Problema de Reserva. 


\section{Contents}

1 Introduction $\quad 11$

2 Chance constrained programming $\quad \mathbf{1 5}$

2.1 An example 15

2.2 Single and joint constraints 16

$\begin{array}{lll}2.3 & \text { Some properties and special cases } & 18\end{array}$

3 Sample Average Approximation $\quad 21$

3.1 Theoretical background for SAA 21

4 Two applications of SAA $\quad 27$

4.1 Portfolio problem 27

4.2 A blending problem 35

5 From separated to joint variables: the hurdle-race problem 39

5.1 The hurdle-race problem and comonotonicity 40

5.2 The joint hurdle-race problem 41

5.3 Stochastic hurdles 44

$\begin{array}{lll}6 & \text { Conclusion } & 47\end{array}$ 
Ah! Doutor! Doutor!... Era mágico o título, tinha poderes e alcances múltiplos, vários, polifórmicos... Era um pallium, era alguma coisa como clâmide sagrada, tecida com um fio tênue e quase imponderável, mas a cujo encontro os elementos, os maus olhares, os exorcismos se quebravam. De posse dela, as gotas de chuva afastar-se-iam transidas do meu corpo, não se animariam a tocar-me nas roupas, no calado sequer. O invisvel distribuidor dos raios solares escolheria os mais meigos para me aquecer, e gastaria os fortes, os inexoráveis, com o comum dos homens que não é doutor. Oh! Ser formado, de anel no dedo, sobrecasaca e cartola, inflado e grosso, como um sapo antes de ferir a martelada à beira do brejo; andar assim pelas ruas, pelas praças, pelas estradas, pelas salas, recebendo cumprimentos: Doutor, como passou? Como está, doutor? Era sobre-humano!...

Lima Barreto, Recordações do Escrivão Isaías Caminha. 